\title{
Study of fractures in Precambrian crystalline rocks using field technique in and around Balarampur, Purulia district, West Bengal, India
}

\author{
Monalisa Mitra $^{1,2, *}$ and TAPAs ACharya ${ }^{1,3}$ \\ ${ }^{1}$ Department of Geology, Durgapur Government College, University of Burdwan, Durgapur 713 214, India. \\ ${ }^{2}$ Present Address: Haryana Space Application Centre (HARSAC), Department of Science and Technology, \\ CCS HAU Campus, Hisar 125 004, India. \\ ${ }^{3}$ Present Address: Department of Geology, Hooghly Mohsin College, University of Burdwan, \\ Chinsurah 712 101, India. \\ *Corresponding author.e-mail: mitramonalisa4@gmail.com
}

Location of recharge zone in Precambrian crystalline rock is still unclear. The present study attempts to perform a detailed analysis of the joints/fractures developed in a Precambrian metamorphic terrain in and around Balarampur in Purulia district of West Bengal, India using bedrock data. The analysis shows that the orientations of major fracture trends are variable along with varying lithological units and structural affinities. The application of lithology-based analysis technique identifies highly predominant fracture frequency and fracture aperture in mica schist and phyllite in the area. This property is not evident in the granite gneiss and epidiorite. The moderate to high fracture permeability value is also associated with the fractures occurring in the shear zone. Mica schist and phyllite associated with the shear zone may represent a permeable recharge zone in the region.

\section{Introduction}

Mapping of structural features using bedrock data has been an integral part of many groundwater exploration programmes in hard rock terrain. Several workers (Braathen 1999; Henriksen and Braathen 2006; Boutt et al. 2010) have recognized enhanced permeability amongst hydraulically significant fractures and high fracture frequencies. In areas where bedrock has a low primary porosity, the intersection of secondary structural features is important for productive groundwater wells. The influence of size and distribution of apertures of fractures on permeability status of hard rock terrain is shown by several workers (Tsang and Witherspoon 1981; Oda 1985; Brown 1987; Bertels et al. 2001; Auradou et al. 2005; Matsuki et al. 2006; Pan et al. 2010).
Lack of adequate potable and agricultural water supplies inhibits the progress of developing countries and is the cause of considerable hardship to human worldwide. A thorough hydrogeological understanding is often a critical issue for cost effective water development designed to alleviate these hardships. In many developing countries, remote sensing data often comprise a majority of the existing spatial information available for extensive areas. Structural features in hard rock are often visible on remote sensing data as topographic, drainage, vegetation, or soil tonal anomalies. Natural lineaments or linear surface elements interpreted directly from satellite imagery and geophysical map have been called fracture traces and many other names (O'leary et al. 1976; Parizek 1976; Garza and Slade 1986) are used extensively for water resource

Keywords. Fracture; porosity; permeability; recharge zone; transmissive. 
investigations (Boyer and McQueen 1964; Lattman and Parizek 1964; Peterson 1980; Brown 1994; Mah et al. 1995; Dhakate et al. 2007) and structural geologic studies (Blanchet 1957; Henderson 1960; Hodgson 1961; Lattman and Segovia 1961; Caran et al. 1982; Rahiman and Pettinga 2008; Kazemi et al. 2009) considering that lineaments are surface expressions of joints/fractures.

There exists a few studies investigating lineaments (Mitra and Acharya 2014) and subsurface bedrock fractures (Mallik et al. 1983; Nag 1999) in and around Balarampur. The common assumption in fracture mapping for exploration of groundwater is that these features represent vertical zones of fracture concentration. An understanding of the threedimensional characteristics of identified structural features is important for successful well sitting, but it is difficult to obtain these features using remote sensing data only. Final well sitting strategies should include supporting evidences from other data sources, such as geophysical investigations, or feedback from subsequent well drilling and evaluation. Among the various geophysical methods of groundwater investigation, the electrical resistivity method has the widest adoption in groundwater exploration (Olorunfemi et al. 1999; Afolayan et al. 2004; Ariyo 2007). Establishing relationships between structural data and hydrologic phenomena can maximize the efficiency of a water development project.

Water supply problems in metamorphic crystalline rocks are the result of three reasons: (i) secondary porosity of the rocks, (ii) underlying heterogeneous characteristics, and (iii) problem of identification of suitable fractures. Water supply wells have commonly been located on the basis of local geological studies followed by drilling into the crystalline rocks, with little success rate except by-chance finding. With the advent of fracturemapping techniques, locations for high yield wells have been recommended. The drilling success rate of the wells from World Vision's Ghana Rural Water Project (GRWP), was defined as the percentage of wells with an yield above $10 \mathrm{l} / \mathrm{min}$, had averaged approximately $55 \%$, due to difficult hydrological conditions (Sander et al. 1997). This means that significant resources were spent by drilling dry boreholes. The true success rate on site-to-site basis was, however, lower than $55 \%$, as at the same successful site, two or more wells were commonly drilled. This means that to assess the potential of fracture, data for groundwater development have to be further developed. The hydrogeological function of a mapped fracture could, for example, be a highly transmissive recharge zone or a potential flow barrier, such as filled up fractures. This method, however, depends on a thorough field investigation of a large number of features representing the area being studied. Other investigators (Banks et al. 1992, 1993), however, have found through investigations from tunnel projects in crystalline rock that the largest fracture zones often cause few water leakage problems, due to clay mineralization, while small to intermediate fracture zones can be significantly more transmissive, causing larger leakage problems. In recent years, the techniques for location of high yielding wells have involved the correlation analysis of lineaments from satellite imagery and fracture zones from field outcrops. These observations based on practical experiences clearly suggest that the problem of locating high yield wells still exists and no solution has been found so far.

The study area, as given in figure 1, is located in and around Balarampur, Purulia district, which is semi-arid and the most draught-prone in West Bengal, India and lies within $23^{\circ} 02^{\prime} 47^{\prime \prime}-23^{\circ} 07^{\prime} 41^{\prime \prime} \mathrm{N}$ and $86^{\circ} 10^{\prime} 00^{\prime \prime}-86^{\circ} 19^{\prime} 02^{\prime \prime} \mathrm{E}$.

This particular area, which is underlain by jointed/fractured metamorphic rocks, provides good exposure and thus facilitates to carry out critical analysis of fractures. Main objectives of the present study were to record the structural features of the rocks and to analyze the fracture patterns and fracture frequency and fracture aperture in the bedrocks and its hydrological significance and also to find out the technique for identifying the locales of the potential recharge zone in Precambrian metamorphic crystalline rocks. Detailed study of fractures in this area was made from rock exposures. Total fractures in the study area $(\sim 132.9$ $\mathrm{km}^{2}$ ) have been categorized on the basis of lithological and structural affinities. The fracture data obtained from the field exposures have been analysed, by taking into account the dominant azimuth sets, frequency and aperture to identify the groundwater flow path in the region. Very high rate of evapotranspiration and soil erosion, and moderate to low annual rainfall cause a major problem of potable water and groundwater availability in the region. In Purulia district, no proper investigation has been carried out to develop the technique to locate the areas of groundwater recharge.

\section{Geological set-up and climate of the area}

The study area comprises a part of the eastern Chhotanagpur plateau in the eastern India Shield. This area of Precambrian hard rock terrain bears the evidence of polyphase deformation resulting generations of structural elements (both planer and linear) on different tectonic phases.

The study area is located at the junction of Chhotanagpur Granite Gneissic Complex (CGGC) and the Singhbhum Group of rocks (SG), exposing 

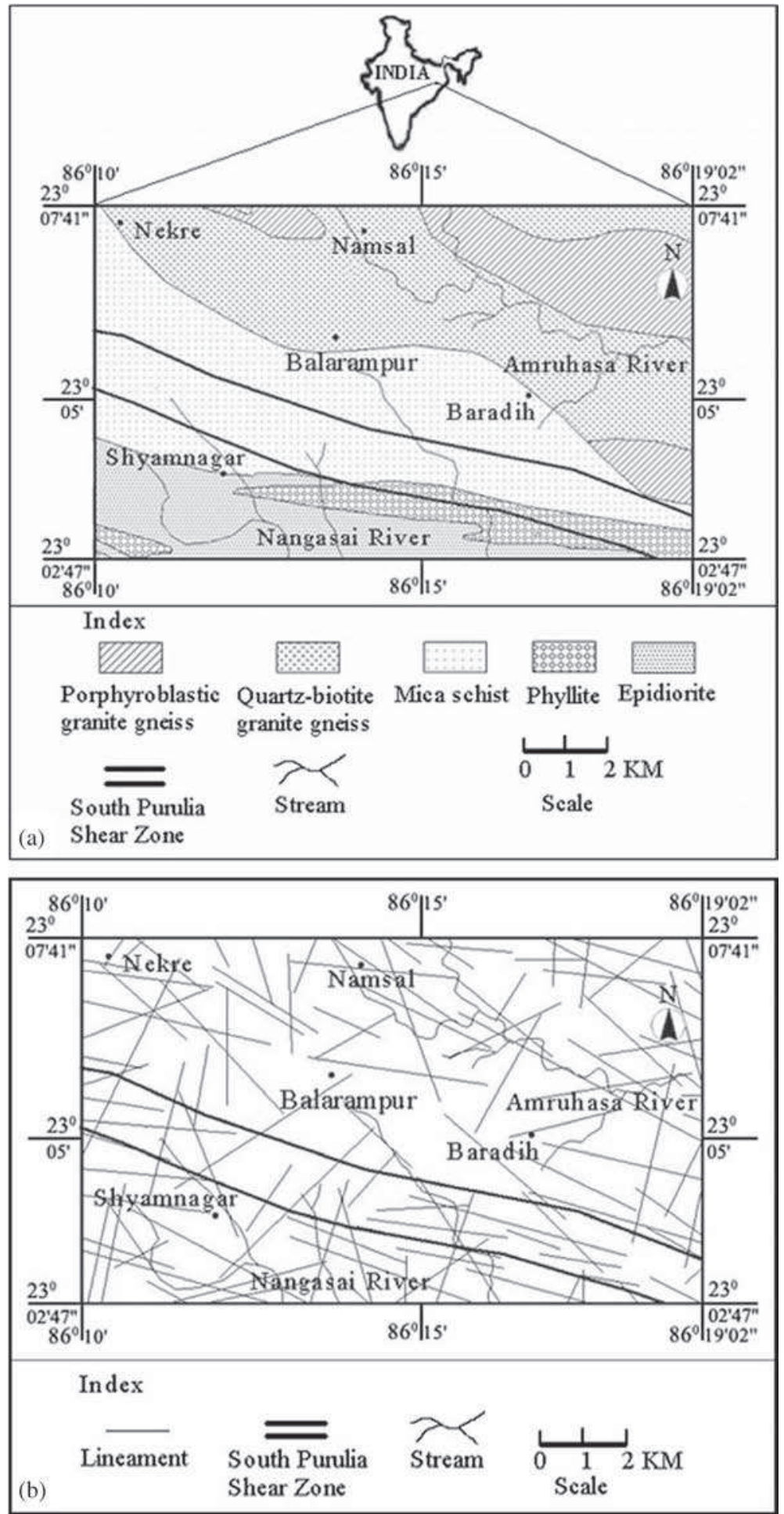

Figure 1. (a) Geological map of the study area in Purulia district, West Bengal, India and (b) map of the area showing the geologic lineaments.

metamorphic rocks of Proterozoic age (Gupta and Basu 2000) (figure 1a). At the north, the CGGC is a part of the Chhotanagpur craton consisting varieties of granite gneisses, such as quartzbiotite granite gneiss and porphyroblastic granite gneiss. The SG rocks, exposing at the south belongs to Singhbhum orogenic belt and comprises chiefly mica schist and phyllite. NW-SE foliations are well developed both in the CGGC and in the metasedimentaries of Singhbhum Group (Geological quadrangle map 73I, 1948). The foliations in the area statistically dip high $\left(>57^{\circ}\right)$ 
towards north. The metasediments of SG are interlayered with basic bodies, locally described as epidiorite sills, which may have a strong genetic connection with the Dalma Volcanics (Geological quadrangle map 73I, 1948). Presence of more than one generation of minor folds indicates imprints of polyphase deformation of the rocks. Geometry of the first generation fold is not preserved due to absence of exposures of competent horizons.

Lithologically, the area is largely covered by granitic rocks of the Precambrian Chhotanagpur Complex in which some east-west trending patches of older metasedimentary and metabasic rocks which are stratigraphically and petromineralogically comparable to the 'Singhbhum Group' of rocks of age 2300-2400 Ma are enclosed and in places considerably digested by the younger granitic material. The basement for the older metasedimentes is not recognized but petromineralogy of the sediments indicates an older granitic provenance. A sequence of dominantly shale and impure limestone, with some intercalated sandstone bodies existed prior to folding and metamorphism (Baidya 1992). The calc-magnesian sediments are now transformed into calc-silicate rocks. Metasomatic effect of the granites on these calcsilicate rocks caused some skarn rocks which are principally composed of quartz, diopside, microcline and calcite with accessories like epidote, sphene and plagioclase. The older basic rocks comprising amphibolites mainly and some hornblende schist occur as elongated patches, lenses and bands concordant with the metasediments and are co-folded with them. Granitic rocks vary considerably in composition, structure and texture. The composite gneiss representing the oldest unit among the granitoids, comprises mainly of some migmatites and biotite-granite gneisses. The composite gneiss shows continuity of all structural elements found in the adjacent metasedimentary rocks and amphibolites. The porphyroblastic biotite-granitoid is relatively coarse grained and crudely foliated, having more or less sharp contact with the metasediments and composite gneiss. Complex folds within the metasediments and composite gneiss are absent in the porphyroblastic biotite granitoid. Pegmatites, aplite and hydrothermal quartz bodies occur as nearly eastwest trending lenses and veins closely associated with granitoids.

From the study of satellite imageries and photographs, the area displays prominent east-west lineaments, which are intercepted by a system of north-south lineament and occasionally by NW$\mathrm{SE}$ lineaments. Some elongated patches of metabasics like amphibolites are entrapped within the phyllite zone.

\subsection{Structure of the area}

The 'south Purulia shear zone' (Baidya 1992) occurs in the study area which trends almost $\mathrm{E}-\mathrm{W}$ and passes just south of Balarampur. This shear zone contains important phosphate mineralization including apatite. Field checking of the satellite imagery revealed the presence of a prominent $\mathrm{E}-\mathrm{W}$ trending or nearly so pervasive zone of structural weakness which is characterized by the development of very prominent schistosity or cleavage or mylonitic foliation. The abrupt orthogonal turns of different $\mathrm{E}-\mathrm{W}$ flowing streams like Nangasai, Kumari, Amruhasa, etc., is mainly the effect of $\mathrm{N}-\mathrm{S}$ younger fracture system transgressing the schistosity. Photogeological study also reveals that water bodies like ponds and tanks are much more frequent in the region of metasediments than in the granitic terrains. Evidences of shear forces acting along some $\mathrm{E}-\mathrm{W}$ trending, nearly vertical weak planes, during the third tectonic period are practically very scanty in region of southern Purulia shear zone. In this area such structural elements are mainly represented by some shearjoints and fractures in the granitic rocks, pegmatites and quartz veins. These shear joints, fractures and faults strike $\mathrm{E}-\mathrm{W}$, in general, with $60^{\circ}$ to nearly vertical dips.

\subsection{Climate and rainfall}

Balarampur like all other places in Purulia district is known as drought-prone area and falls within the semi-arid region of the state of West Bengal, India. The entire district is characterized by a high evaporation rate. This region has a subtropical climate, the temperature varying over a wide range during the year, $7^{\circ}-46^{\circ} \mathrm{C}$ in summer in average. The area experiences a marked seasonal variation with pronounce variability of rainfall and occurrence of drought condition due to its interior location, i.e., approximately $300 \mathrm{~km}$ away from the sea.

Average annual rainfall of the district is in the order of $1350 \mathrm{~mm}$, the main source of the rains being the south-west monsoon. The three months July, August and September account for the major portion of the year's rainfall.

\section{Methodology}

The lithology (figure 1a) and lineament (figure 1b) maps have been created from the Geocoded 73$\mathrm{I} / 4,73-\mathrm{I} / 8$ (1) and 73-I/8 (2) satellite imageries of IRS-P6 standard (band 23 4) false colour composite (FCC) on the base map, which is prepared using the Survey of Indian toposheets numbered $73-\mathrm{I} / 4$ and $73-\mathrm{I} / 8$ at $1: 50,000$ scale. Lineament map of the area is prepared by visual 
interpretation from satellite image. It is based on variation of soil tone, vegetation, topographic and drainage linearity (Lillesand 1989; Drury 1990; Gupta 1991). The non-structural lineaments also known as false lineaments have been eliminated by comparing all the lineaments with the corresponding toposheets $(73-\mathrm{I} / 4,73-\mathrm{I} / 8)$ and field verification. The geologic map is also prepared by visual interpretation and field verification.

\subsection{Measurements of fractures and joints}

Detailed joint/fracture study in the field show that these structures are usually visible in rock exposures though not all are always identified at every outcrop. Joints are developed in more than one set and with varying azimuth. We have selected those exposures which show a good number of fracture sets, distinct fracture surfaces and 3-D visualization of the exposures. After a careful survey over an exposure and its surroundings, measurements of the attitude (strike and dip) of the predominant and distinct fracture sets have been made with clinometer. For statistical significance, the attitude of a set of fractures has been taken as representative sample of measurements averaging three measurements made with great precision at different points of an outcrop (Mallik et al. 1983). Absence of goodquality exposure at few places led some constraints to collect the field data more sufficiently as in other areas. We have analyzed in detail the structural data featuring joints/fractures of the rocks, obtained from the field. We have used GE Orient software for quantitative and statistical analyses on fractures. Measurements made in the form of angles have been analyzed in terms of a circular distribution. The angular data have been compiled in rose diagrams with the frequency distribution using GE Orient software. Since the measurements have been taken between $0^{\circ}$ and $180^{\circ}$, the circular distributions have been plotted on unit circles with $10^{\circ}$ class intervals, and then the 18 classes have been duplicated before plotting. The rocky outcrops of the terrain are almost everywhere jointed and otherwise fractured into fairly well defined sets resulting from tectonic deformation. There is as well a multitude of joints and fractures that are mostly horizontal or sub-horizontal and have developed as a result of release of overburden stress due to erosional processes. Although these joints and fractures may sometimes be water bearing, the measurements of this feature has not been taken because of their surficial characters. The steeply dipping joints and fractures are the characteristic features of the rocks which are the conduit of water movement into the deeper parts of the rocks forming the water bearing zones in this kind of rock.
In the study area of Balarampur block in Purulia district, joints and future measurements were made at 11 sites where these were best displayed. The sites were distributed throughout the study area to get an overall structural feature of that area. Those joints/fractures dipping $45^{\circ}$ or more are only measured and considered for analysis since we know straight line lineaments are also formed by steeply dipping planes (De'gnan and Clark 2002). The measurement of joints/fractures includes the strike and dip of each steeply dipping joint set. Attitude of the joints has been determined with the help of a clinometer compass by measuring the strike of the joint and the amount of inclination.

\subsection{Fracture attitude}

All the fracture trends have been plotted using rose diagrams in figure 2 separately to show their azimuthal distributions. This figure clearly shows that the fracture geometry is distributed between $20^{\circ}$ and $40^{\circ}$, peaking along $15^{\circ}$ and $35^{\circ}$ directions which are reasonably consistent throughout the entire area.

Exposed in the area are chiefly four lithology types, i.e., granite gneiss, mica schist, phyllite and epidiorite. The fracture trend data as recorded from these lithologies have been classified in table 1 , and their rose diagrams in figure 3 to understand the effects of lithology on them. The granite gneiss has developed fractures largely trending along NNE-SSW directions (figure 3a). The mica schist has fractures orienting along $\mathrm{E}-\mathrm{W}$ and $\mathrm{NW}-$ $\mathrm{SE}$ directions (figure $3 \mathrm{~b}$ ). In phyllite, the fracture trends are given by NNE-SSW and NW-SE directions (figure 3c). The epidiorites have the fractures along $\mathrm{E}-\mathrm{W}$ and $\mathrm{N}-\mathrm{S}$ directions (figure $3 \mathrm{~d}$ ).

The area has been divided into three domains: (1) region lying north of shear zone (D1), (2) the region within the shear zone (D2), and (3) the region lying south of shear zone (D3), as shown in figure 4 . The fracture trends of the three domains

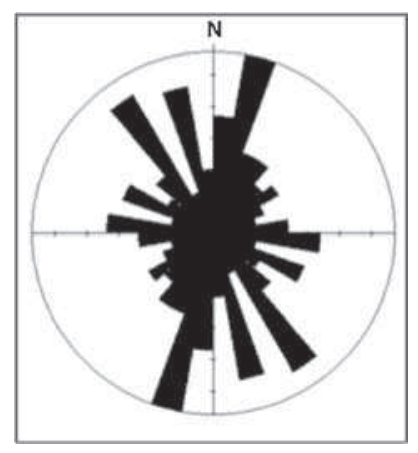

Figure 2. Azimuth-frequency (rose) diagram of fracture orientation in the study area. 
Table 1. Dominant direction of major fractures in different lithological units.

\begin{tabular}{ll}
\hline Lithology & $\begin{array}{l}\text { Major fracture } \\
\text { strike direction }\end{array}$ \\
\hline Granite gneiss & $\mathrm{N}-\mathrm{S}$ \\
Mica schist & $\mathrm{E}-\mathrm{W}, \mathrm{NW}-\mathrm{SE}$ \\
Phyllite & $\mathrm{N}-\mathrm{S}$ \\
Epidiorite & $\mathrm{E}-\mathrm{W}, \mathrm{N}-\mathrm{S}$ \\
\hline
\end{tabular}

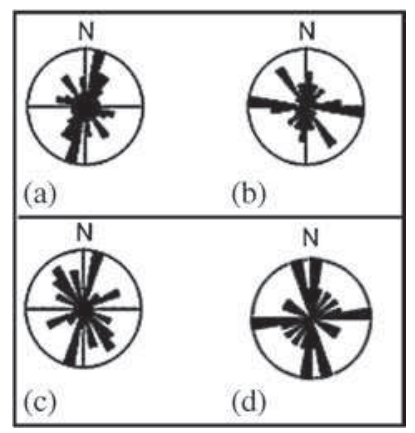

Figure 3. Azimuth-frequency (rose) diagrams showing fracture orientation in the lithology types: (a) granite gneiss, (b) mica schist, (c) phyllite, and (d) epidiorite.

have been listed in table 2 and dominant trends of fracture have been presented in the rose diagrams (figure 4). In the north of shear zone (D1), the fracture trends are along $\mathrm{N}-\mathrm{S}$ direction (figure 4a). The domain, D2 shows fracture trends along the $\mathrm{E}-\mathrm{W}$ direction (figure $4 \mathrm{~b}$ ). In the region south of shear zone (D3), the dominant fracture trend is along NE-SW direction (figure 4c).

\subsection{Fracture frequency}

Frequency of joints/fractures, measured as number of joint planes of a particular set crossed in a perpendicular traverse of $1 \mathrm{~m}$, ranges from 1 to $100 / \mathrm{m}$ at $95 \%$ confidence level. It is assumed that fractures with higher frequency, i.e., more closely spaced fractures, may represent more potentially transmissive bedrocks (Mabee and Hardcastle 1997). The scatter-plots, showing relation between fracture strike and fracture frequency data, have been constructed using Statistica software at 95\% confidence level for the three domains, D1, D2 and D3 in figure 5.

Graphs generated from the fracture frequency database form field appear to indicate some interesting features. It may be noted from figure 5(b) that the scatter-plot curve of the shear zone (D2) shows highest frequency $(60 / \mathrm{m})$ of the fracture set striking along $\mathrm{E}-\mathrm{W}$ direction. The scatter-plot curve in domain 3 shows high frequency $(50 / \mathrm{m})$ for the fracture set striking $\mathrm{E}-\mathrm{W}$ (figures $5 \mathrm{c}$ ). The scatter-plot curve of domain 1 yields low frequency for all the fracture sets $(<20 / \mathrm{m})$ in general (figures 5a).

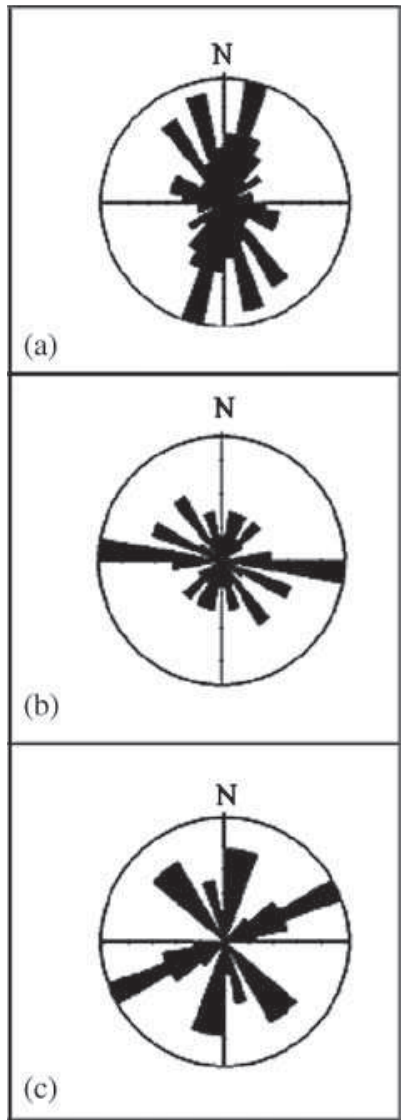

Figure 4. Fracture rosettes in the (a) northern domain (D1), (b) shear zone (D2) and (c) southern domain (D3).

Table 2. Dominant strikes of major fractures in the three domains.

\begin{tabular}{lc}
\hline Domain & $\begin{array}{c}\text { Major lineament } \\
\text { trend direction }\end{array}$ \\
\hline North of shear zone (D1) & $\mathrm{N}-\mathrm{S}$ \\
Shear zone (D2) & $\mathrm{E}-\mathrm{W}$ \\
South of shear zone (D3) & $\mathrm{NE}-\mathrm{SW}$ \\
\hline
\end{tabular}

Variations of frequencies of fractures have been analyzed on the basis of lithological and structural differences. The scatter-plots, showing relation between fracture strike and fracture frequency data, have been plotted using Statistica software at $95 \%$ confidence level for quartz-biotite granite gneiss, porphyroblastic granite gneiss, mica schist, mica schist within shear zone, mica schist outside shear zone, phyllite and epidiorite in figure 6 .

Fracture frequency graphs thus generated show significant differences among the scatter-plot curves. It may be noted from figure $6(\mathrm{~d})$ that the scatter-plot curve of the mica schist within shear zone shows highest frequency $(100 / \mathrm{m})$ of the fracture set striking along NW-SE direction. The scatter-plot curve in mica schist shows high frequency for the fracture sets striking NW-SE $(85 / \mathrm{m})$ and $\mathrm{E}-\mathrm{W}(50 / \mathrm{m})$ (figures $6 \mathrm{c}, \mathrm{d})$. The 


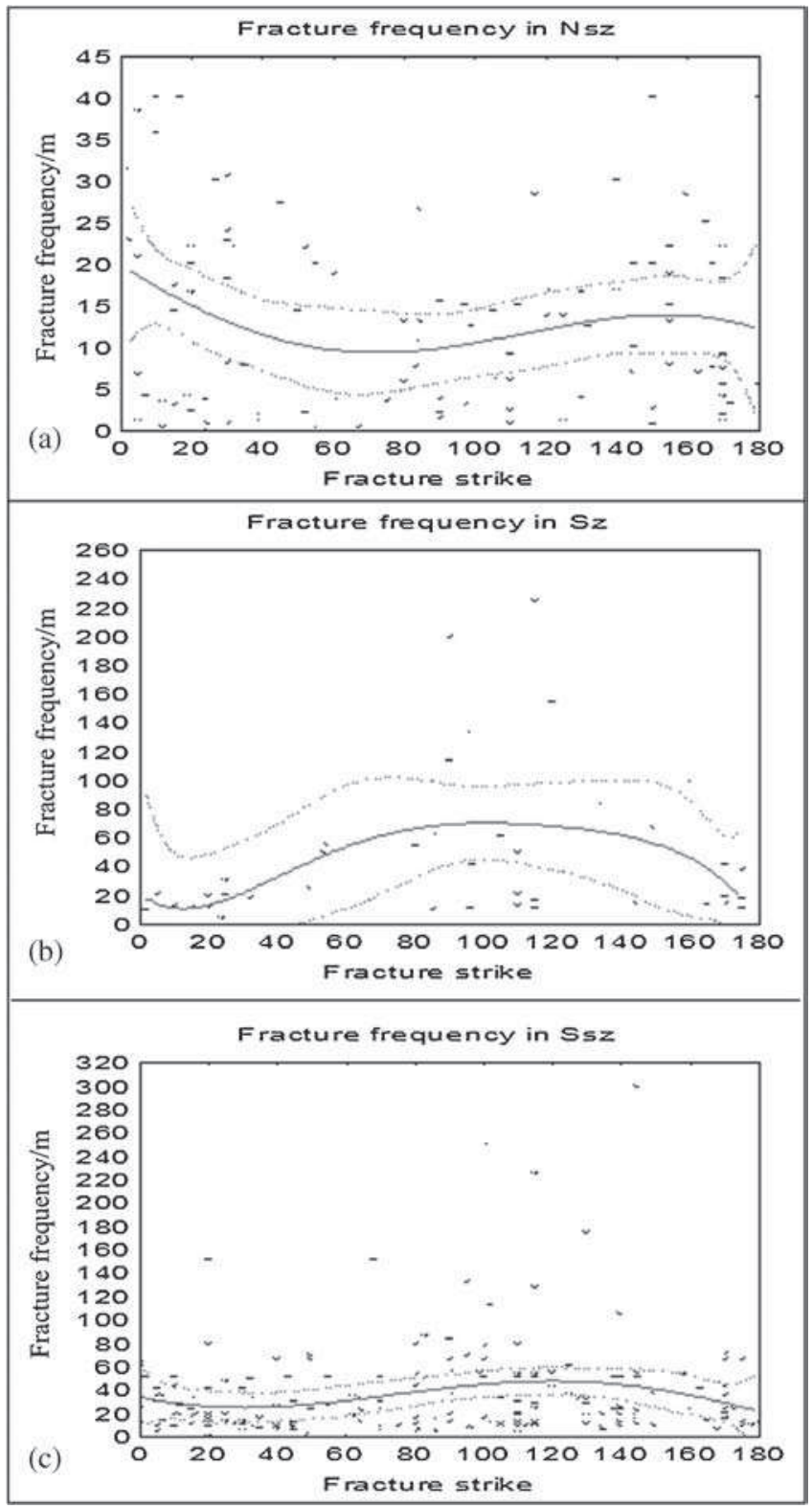

Figure 5. Graphs illustrating the relationship between fracture frequency and fracture strike (a) northern domain (D1), (b) shear zone domain (D2), and (c) southern domain (D3).

scatter-plot curve of phyllite also yields high frequency $(60 / \mathrm{m})$ for all the fracture sets striking along E-W direction (figures 6f). The scatterplot curves of quartz-biotite granite gneiss (figure $6 a)$, porphyroblstic granite gneiss (figure $6 \mathrm{~b}$ ), mica schist outside shear zone (figure $6 \mathrm{e}$ ) and epidiorite (figure $6 \mathrm{~g}$ ) yield low frequency $(<20 / \mathrm{m})$ for all the fracture sets.

\subsection{Fracture aperture}

Trend of a single river is markedly different from place to place and shows almost rectilinear pattern of flow. The river-trend in any region is parallel to the trend of the joint set which exhibits anomalously high fracture aperture $(>5 \mathrm{~mm})$ with moderate to high fracture frequency $(10-60 / \mathrm{m})$. It is assumed that fracture aperture plays a significant role in permeability of the fractured aquifers, hence, the movement of water within the fractures. Aperture of fractures in the study area varies from hairline size to $8 \mathrm{~mm}$ at $95 \%$ confidence level of the dataset. The scatter-plots, showing relation between fracture strike and fracture aperture data, have been constructed using Statistica software at 95\% confidence level for the three domains, D1, D2 and D3 in figure 7.

Graphs generated from the fracture aperture database form field which appear to indicate an overall moderate value of aperture of fractures $(3 \mathrm{~mm})$ except domain 1 showing low value of aperture $(<3 \mathrm{~mm})$. The scatter-plot curves of domains 2 and 3 yield moderate aperture for the fracture sets striking $\mathrm{E}-\mathrm{W}$ and $\mathrm{N}-\mathrm{S}, \mathrm{E}-\mathrm{W}$ respectively (figure $7 \mathrm{~b}$ and $\mathrm{c}$ ). It may be noted from figure 7 (a) that the scatter-plot curves of the domain 1 shows an overall low value of aperture of fractures in general.

Variations of aperture of fractures have been analyzed on the basis of lithological and structural differences. The scatter-plots, showing relation between fracture strike and fracture aperture data, have been plotted using Statistica software at $95 \%$ confidence level for quartz-biotite granite gneiss, porphyroblastic granite gneiss, mica schist, mica schist within shear zone, mica schist outside shear zone, phyllite and epidiorite in figure 8.

Fracture aperture graphs thus generated also show interesting features. The scatter-plot curve for porphyroblastic granite gneiss (figure 8b) shows a high value of aperture $(8 \mathrm{~mm})$ for the fracture set striking $\mathrm{N}-\mathrm{S}$. The scatter-plot curve in mica schist within shear zone and epidiorite show moderately high aperture $(4 \mathrm{~mm})$ for the fracture sets striking NW-SE and N-S respectively (figure 8d and g). The scatter-plot curve of mica schist outside shear zone also yields moderate aperture $(3 \mathrm{~mm})$ for the fracture sets striking along $\mathrm{N}-\mathrm{S}$ direction (figures $8 \mathrm{e}$ ). The scatter-plot curves of quartz-biotite granite gneiss (figure 8a), mica schist (figure 8c) and phyllite (figure 8f) yield low aperture $(<3 \mathrm{~mm})$ for all the fracture sets.

\section{Results and discussion}

The fractures measured from field exposures have been analyzed for fracture attitude, frequency, aperture and filling.

$34 \%$ of all the fractures measured in the field are oriented along $\mathrm{N}-\mathrm{S}$ direction. Exposed in the area are chiefly four lithology types, i.e., granite gneiss, mica schist, phyllite and epidiorite. 


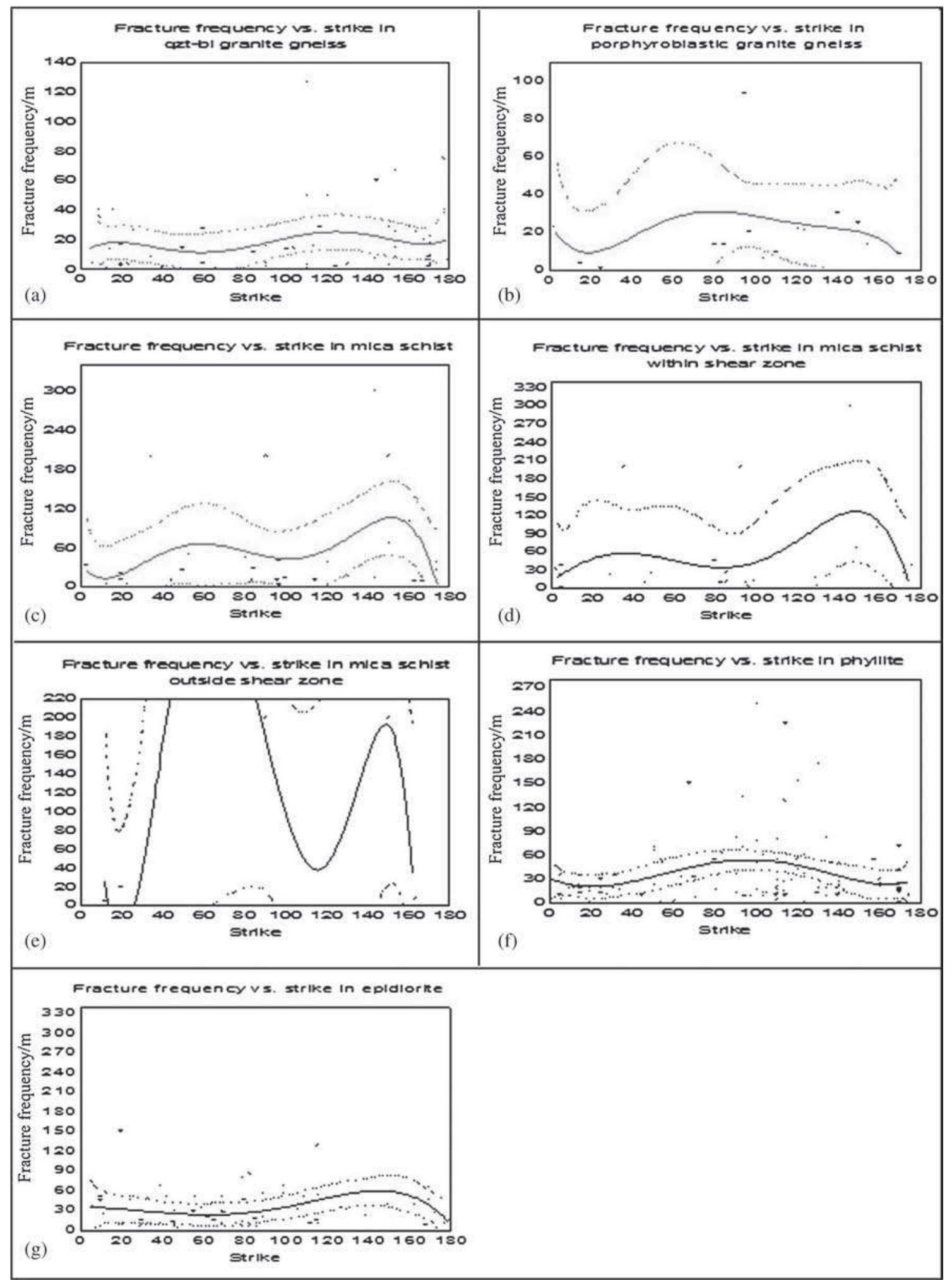

Figure 6. Graphs illustrating the relationship between fracture frequency and fracture strike (a) quartz biotite granite gneiss, (b) porphyroblastic granite gneiss, (c) mica schist, (d) mica schist within shear zone, (e) mica schist outside shear zone, (f) phyllite, and (g) epidiorite.

Fracture frequency analysis shows marked differences of characteristic fracture frequencies among fracture sets of different domains and lithologies. Domain-wise analysis of fracture frequency shows an interesting result. Domain within shear zone, i.e., D2 represents very high frequency $(>60 / \mathrm{m})$ of $\mathrm{E}-\mathrm{W}$ striking fractures, thus indicating that the $\mathrm{E}-\mathrm{W}$ trending fracture sets are very closely 


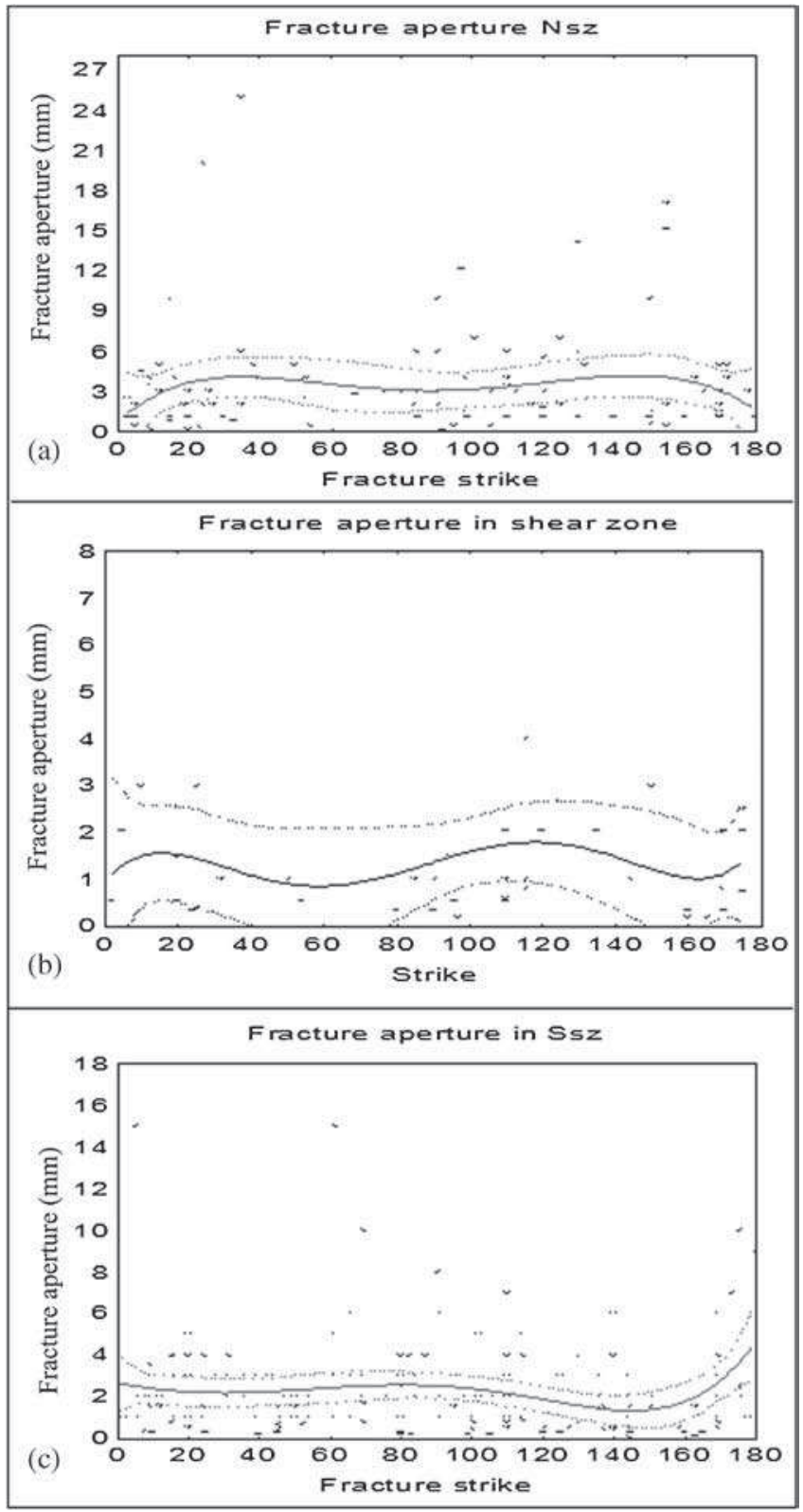

Figure 7. Graphs illustrating the relationship between fracture aperture and fracture strike (a) northern domain (D1), (b) shear zone domain (D2), and (c) southern domain (D3).

spaced. Whereas, the fractures trending along N-S direction are very widely spaced as interpreted from their very low value of fracture frequency $(\sim 10 / \mathrm{m})$. Very interestingly, D2 domain shows dominant fractures along $\mathrm{N}-\mathrm{S}$ and $\mathrm{E}-\mathrm{W}$ directions. Surprisingly contrasting fracture frequency exhibited by $\mathrm{N}-\mathrm{S}$ and $\mathrm{E}-\mathrm{W}$ trending fractures of this domain suggests a possible role of frequency of fractures to produce preferential water passage. Fractures trending along $\mathrm{E}-\mathrm{W}$ direction exhibit high fracture frequency and therefore produce dominant groundwater flow along $\mathrm{E}-\mathrm{W}$ direction. The other major fractures trending along $\mathrm{N}-\mathrm{S}$ direction display low fracture frequency and consequently do not represent any major groundwater flow along this direction. D3 domain also represents high fracture frequency value $(>50 / \mathrm{m})$ of $\mathrm{E}-\mathrm{W}$ trending fractures and low frequency value $(\sim 20 / \mathrm{m})$ of $\mathrm{N}-\mathrm{S}$ trending fractures. Not surprisingly groundwater flow direction is oriented along E-W direction, while the major fracture trends are along both $\mathrm{N}-\mathrm{S}$ and $\mathrm{E}-\mathrm{W}$ directions. D1 domain exhibits an overall very low value $(<20 / \mathrm{m})$ of fracture frequency shown by all the fractures. Very interestingly, dominant fractures in this domain showing N-S trend do not represent any major groundwater flow paralleling the fractures. Again, the absence of major groundwater flow may be assigned to the very low value of fracture frequency in this domain. Analysis of fracture frequency characteristic to the fractures occurring within particular lithologies shows an exciting result. Quartz-biotite granite gneiss, porphyroblastic granite gneiss and epidiorite exhibit an overall very low value $(<20 / \mathrm{m},<25 / \mathrm{m}$ and $<10 /$ m respectively) of fracture frequencies shown by all the fractures. Very significantly, dominant groundwater flow is absent in quartz-biotite granite gneiss, porphyroblastic granite gneiss and epidiorite. Quartz-biotite granite gneiss and epidiorite show dominant fractures along N-S direction and porphyroblastic granite gneiss exhibits $\mathrm{E}-\mathrm{W}$ trending major fractures. But interestingly none of the fracture trends demonstrate major groundwater flow in this region. Mica schist and phyllite display very high frequency $(>85 / \mathrm{m}$ and $>60 / \mathrm{m}$ respectively) of $\mathrm{E}-\mathrm{W}$ striking fractures. Whereas, other fractures exhibit low value of fracture frequency $(<20 / \mathrm{m})$. Very interestingly, mica schist and phyllite show major groundwater flow along E-W direction, paralleling the major fracture direction. Dominant fractures trending along $\mathrm{E}-\mathrm{W}$ direction in the mica schist within shear zone exhibit maximum fracture frequency in the study area, therefore producing major groundwater flow along $\mathrm{E}-\mathrm{W}$ direction. Mica schist outside shear zone demonstrates major fractures trending along $\mathrm{N}-\mathrm{S}$ direction with low fracture frequency $(<10 / \mathrm{m})$ and consequently do not represent any major groundwater flow along this direction.

Detailed analysis of fracture aperture has been carried out for different domains and litologies. D1, D2, D3 domains and all lithologies demonstrate low values $(<3 \mathrm{~mm})$ of fracture apertures, except the fractures occurring in porphyroblastic granite gneiss. $\mathrm{N}-\mathrm{S}$ trending fractures, with low fracture frequency, occurring in porphyroblastic granite gneiss exhibit drastically very high value of fracture aperture which is greater than $8 \mathrm{~mm}$. The fracture aperture of $\mathrm{N}-\mathrm{S}$ trending fractures in porphyroblastic granite gneiss is abruptly very high compared to other fracture aperture values. Very remarkably porphyroblastic granite gneiss 


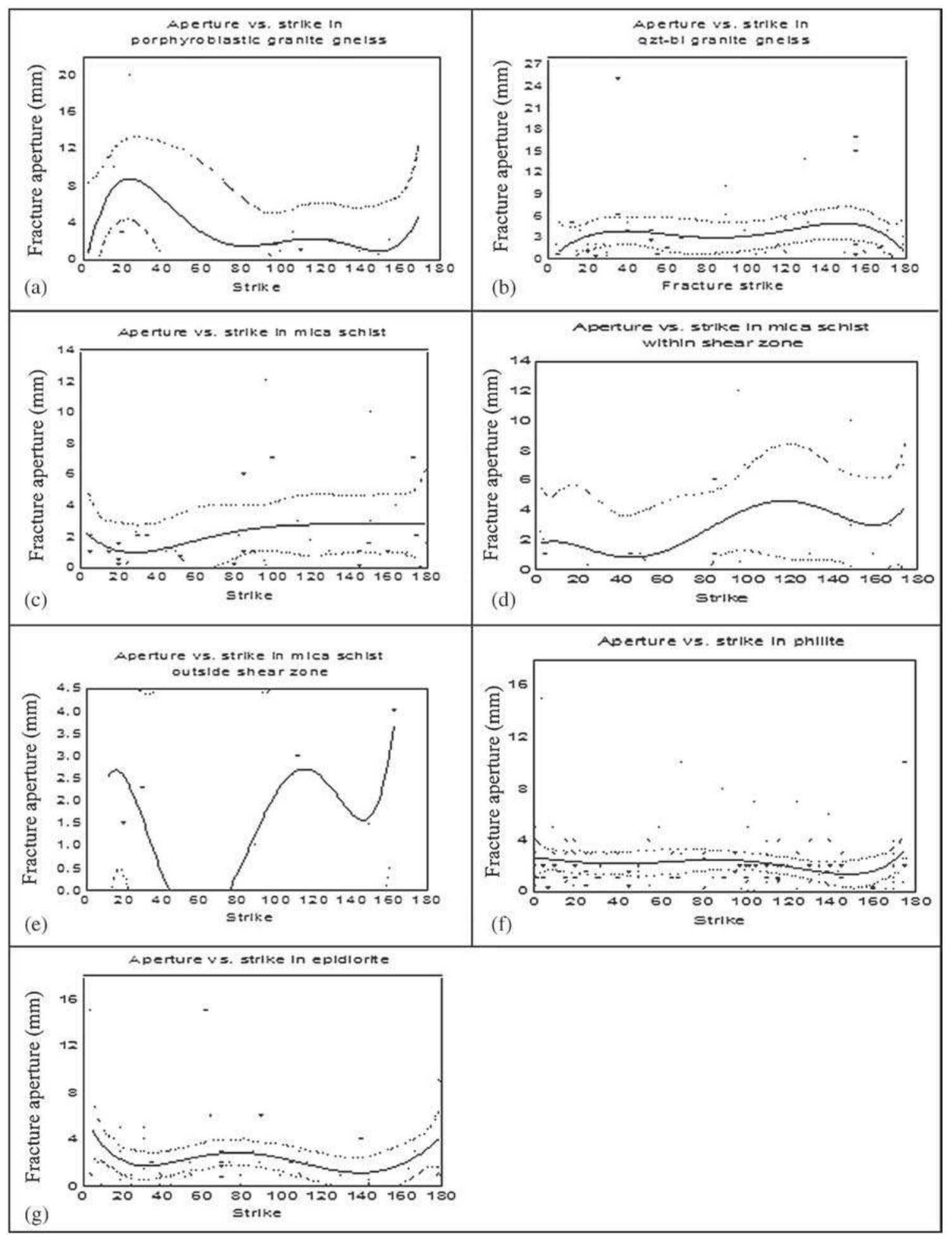

Figure 8. Graphs illustrating the relationship between fracture aperture and fracture strike (a) quartz biotite granite gneiss, (b) porphyroblastic granite gneiss, (c) mica schist, (d) mica schist within shear zone, (e) mica schist outside shear zone, (f) phyllite, and (g) epidiorite.

displays fracture-correlated lineaments along $\mathrm{N}-\mathrm{S}$ direction. Presence of fractures characterized by very high value of fracture aperture may perhaps indicate the major groundwater flow pattern. Therefore, it points towards the fact that fracture aperture greater than $8 \mathrm{~mm}$ may represent conduits for groundwater flow. Braathen (1999), Henriksen and Braathen (2006) rightly pointed out enhanced permeability associated with a high fracture frequency. There exists no previous study 
regarding the significance of fracture frequency and fracture aperture for generation of groundwater flow path.

\section{Conclusion}

Fracture frequency and fracture aperture play a significant role for representing the groundwater flow path. Both fracture frequency and fracture aperture facilitate the movement of groundwater within the fractures. High fracture frequency means closely spaced fractures. More closely the fractures are placed, more is the tendency of groundwater to flow along that closely spaced fractures. Fracture aperture controls the openness of the fractures. Openness of the fractures is assigned to the permeability of the fracture. More permeability imparts more groundwater movement within the fractures. Present study shows an appreciable influence and control of presence of shear zone and both fracture frequency and fracture aperture to produce the conduits of groundwater recharge zone.

\section{Acknowledgements}

The first author Monalisa Mitra is greatly obliged to her guide, Dr. Tapas Acharya and The Burdwan University for providing a platform to complete her dissertation work during M.Sc degree.

\section{References}

Afolayan J F, Olorunfemi M O and Afolabi O 2004 Geoelectric/electromagnetic VLF survey for groundwater in a basement terrain: A case study; Ife J. Sci. 6(1) 7478.

Ariyo S O 2007 Hydro-geophysical investigations for groundwater at Atan/Odosenbora area, southwestern Nigeria; Ife J. Sci. 9(1) 87-92.

Auradou H, Drazer G, Hulin J P and Koplik J 2005 Permeability anisotropy induced by the shear displacement of rough fracture walls; Water Resour. Res. 41 W09423, doi: 10.1029/2005WR003938.

Baidya T K 1992 Apatite-magnetite deposit in the Chhotanagpur Gneissic Complex, Panrkidih area, Purulia district, West Bengal; Indian J. Geol. 64(1) 88-95.

Banks D, Rohr-Torp E and Skarphagen H 1993 Groundwater resources in hard rock; In: Experiences from the Hvaler study, Southeastern Norway; Memoires of the 24th Congress of AIH, Hydrogeology of Hard Rocks, Oslo, pp. 39-51.

Banks D, Solbjorg M L and Rohr-Torp E 1992 Permeability of fracture zones in a Precambrian granite; Quart. J. Eng. Geol. 25 377-388.

Bertels S P, DiCarlo D A and Blunt M J 2001 Measurement of aperture distribution, capillary pressure, relative permeability, and in situ saturation in a rock fracture using computed tomography scanning; Water Resour. Res. 37(3) 649-662.
Blanchet P H 1957 Development of fracture analysis as an exploration method; Am. Assoc. Pet. Geol. Bull. 40 1748-1759.

Boutt D F, Diggins P and Mabee S 2010 A field study (Massachusetts, USA) of the factors controlling the depth of groundwater flow systems in crystalline fractured-rock terrain; Hydrogeol. J. 18 1839-1854.

Boyer R and Mcqueen J 1964 Comparison of mapped rock fractures and airphoto linear features; Photogram. Eng. Remote Sens. 30 630-635.

Brown N 1994 Integrating structural geology with remote sensing in hydrogeological resource evaluation and exploration; Proceedings of Tenth Thematic Conference in Geologic Remote Sensing, San Antonio, TX, 1, 144-154.

Brown S R 1987 Fluid flow through rock joints: The effect of surface roughness; J. Geophys. Res. 92 1337-1347.

Braathen A 1999 Kinematics of post-Caledonian polyphase brittle faulting in the Sunnfjord region, western Norway; Tectonophys. 302 99-121.

Caran C S, Woodruff C M Jr and Thompson E J 1982 Lineament analysis and inference of geologic structures - examples from the Balcones/Ouachita trend of Texas; University of Texas at Austin, Bureau of Economic Geology; Geological Circular 82(1) 59-69.

De'gnan J R and Clark S F Jr 2002 Fracture-correlated lineaments at Great Bay, southeastern New Hampshire; US Geological Survey Open-File Report 02-13.

Dhakate R, Singh V S, Negi B C, Chandra S and Rao V A 2007 Geomorphological and geophysical approach for locating favorable groundwater zones in granitic terrain, Andhra Pradesh, India; J. Environ. Manag., doi: 10.1016/j.jenvman.2007.07.014.

Drury S A 1990 Image Interpretation; In: Geology, 2nd edn, Chapman \& Hall, London.

Garza L D L and Slade R M 1986 Relations between areas of high transmissivity and lineaments - the Edwards aquifer, Barton springs segment, Travis and Hays counties; In: The Balcones Escarpment, Geology, Hydrology, Ecology and Social Development in Central Texas (eds) Abbott P L and Woodruff CM Jr, The University of Texas Libraries, The University of Texas at Austin, pp. 131-144.

Henderson G 1960 Airphoto lineaments in Mpanda area, western Province, Tanganyika, Africa; Am. Assoc. Pet. Geol. Bull. 44 53-71.

Henriksen H and Braathen A 2006 Effects of fracturelineaments and in situ rock stresses on groundwater flow in hard rocks: A case study from Sunnfjord, western Norway; Hydrogeol. J. 14 444-461.

Hodgson R A 1961 Regional study of jointing in Comb Ridge-Navajo Mountain area, Arizona and Utah; $A m$. Assoc. Pet. Geol. Bull. 45 1-38.

Kazemi R, Porhemmat J and Kheirkhah M 2009 Investigation of lineaments related to groundwater occurrence in a karstic area: A case study in Lar catchment, Iran; Res. J. Environ. Sci. 3(3) 367-375.

Lattman L H and Segovia A V 1961 Analysis of fracture trace pattern of Adak and Kagalaska Islands, Alaska; Am. Assoc. Pet. Geol. Bull. 45 249-251.

Lattman L H and Parizek R R 1964 Relationship between fracture traces and the occurrence of ground water in carbonate rocks; J. Hydrol. 2 73-91.

Lillesand T M 1989 Remote Sensing and Image Interpretation; Wiley, USA.

Olorunfemi M O, Ojo J S and Akintunde O M 1999 Hydrogeophysical evaluation of the groundwater potentials of the Akure Metropolis, southwestern Nigeria; J. Mining Geol. 35(2) 201-228.

Geological Quadrangle Map 73I, 1948, Geological Survey of India, Calcutta. 
Gupta R P 1991 Remote Sensing Geology; Springer-Verlag, Germany.

Gupta A and Basu A 2000 North Singhbhum Proterozoic mobile belt, eastern India - A review; Geol. Surv. India Spec. Publ. 55 195-226.

Henriksen H and Braathen A 2006 Effects of fracturelineaments and in situ rock stresses on groundwater flow in hard rocks: A case study from Sunnfjord, western Norway; Hydrogeol. J. 14 444-461.

Mabee S B and Hardcastle K C 1997 Analyzing outcropscale fracture features to supplement investigations of bedrock aquifers; Hydrogeol. J. 5 21-36.

Mah A, Taylor G R, Lennox P and Balia L 1995 Lineament analysis of Landsat Thematic Mapper Images, Northern Territory, Australia; Photogram. Eng. Remote Sens. 61 761-773.

Mallik S B, Bhattacharya D C and Nag S K 1983 Behavior of fractures in hard rocks - A study by surface geology and radial VES method; Geoexploration 21 181-189.

Matsuki K, Chida Y, Sakaguchi K and Glover P W J 2006 Size effect on aperture and permeability of a fracture as estimated in large synthetic fractures; Int. J. Rock Mech. Min. 43 726-755.

Monalisa Mitra and Tapas Acharya 2014 Study of groundwater prospect zones in metamorphic rocks in Purulia district, West Bengal - An approach from remote sensing and geographical information system; Curr. Trends Technol. Sci. 3(6) 402-407.

Nag S K 1999 Hydrogeomorphic and fracture studies for groundwater investigation in and around Balarampur,
Purulia district, West Bengal; ERIM Int. Con., Vancouver, Canada, VI, pp. 507-514.

Oda M 1985 Permeability tensor for discontinuous rock masses; Geotechnique 35 483-495.

O'leary D W, Freidman J D and Pohn H A 1976 Lineament, linear, lineation: Some proposed new definitions for old terms; Geol. Soc. Am. Bull. 87 1463-1469.

Pan J B, Lee C C, Lee C H, Yeh H F and Lin H I 2010 Application of fracture network model with crack permeability tensor on flow and transport in fractured rock; Eng. Geol. 116 166-177.

Parizek R R 1976 On the nature and significance of fracture traces and lineaments in carbonates and other terrains; Karst Hydrology and Water Resources, Proceedings of the US-Yugoslavian Symposium, Dubrovnik, Yugoslavia, pp. 47-100.

Per Sander, Timothy B Minor and Matthew M Chesley 1997 Ground water exploration based on lineament analysis and reproducibility tests; Ground Water 35 888-894.

Peterson R 1980 Lineament analysis for oil and gas exploration and production in Wyoming; Abstr. Am. Assoc. Pet. Geol. Bull. 64764.

Rahiman T I H and Pettinga J R 2008 Analysis of lineaments and their relationship to Neogene fracturing, SE Viti Levu, Fiji; Geol. Soc. Am. Bull. 120(11-12) 1544-1555.

Tsang Y W and Witherspoon P A 1981 Hydromechanical behavior of a deformable rock fracture subject to normal stress; J. Geophys. Res. 86 9287-9298. 